\title{
CONSUMERS'ACCEPTANCE OF FRESH AND COMBINED METHODS PROCESSED MELON, MANGO AND CASHEW APPLE ${ }^{1}$
}

\author{
RENATA TIEKO NASSU², JANICE RIBEIRO LIMA², \\ MEN DE SÁ MOREIRA DE SOUZA FILHO ${ }^{3}$
}

\begin{abstract}
Fresh and combined methods processed Cantaloupe melons, mangoes and cashew apples were submitted to consumers' acceptance and scored on a nine-point hedonic scale. Fruits were osmotically treated in sucrose syrup with two different concentrations of $\mathrm{SO}_{2}$. Overall acceptance, appearance, aroma, flavor and texture were evaluated. Fresh cashew apples received lower scores for acceptance than processed cashew apples while fresh mangoes were more acceptable than processed mangoes. Acceptance of fresh melons and processed melons was similar. Treatments of the tropical fruits with two different concentrations of $\mathrm{SO}_{2}$ did not demonstrate significant differences between the fruits tested.
\end{abstract}

Index terms: sensory analysis, osmosis, Cucumis melo L., Mangifera indica L., Anacardium occidentale L.

\section{ACEITAÇÃO do CONSUMIDOR DE MELÃO, MANGA E CAJU IN NATURA E PROCESSADOS POR MÉTODOS COMBINADOS}

RESUMO - Melões 'Cantaloupe', mangas e pedúnculos de caju in natura e processados por métodos combinados foram submetidos a testes de aceitação, utilizando-se de escala hedônica de nove pontos. As frutas sofreram tratamento osmótico em um xarope de sacarose com duas diferentes concentrações de $\mathrm{SO}_{2}$. Foram avaliados aceitação global, aparência, aroma, sabor e textura. Pedúnculos de caju in natura obtiveram notas menores para aceitação se comparados aos processados, enquanto mangas in natura foram mais aceitas do que as processadas. A aceitação de melões in natura e processados foi similar. Tratamentos com diferentes concentrações de $\mathrm{SO}_{2}$ não apresentaram diferenças significativas entre os frutos estudados.

Termos de indexação: análise sensorial, osmose, Cucumis melo L., Mangifera indica L., Anacardium occidentale L.

\section{INTRODUCTION}

Production of economically important tropical fruits is mostly distributed in tropical and subtropical zones of less developed countries. Lack of suitable techniques of handling, transportation and storage, and also high perishability lead to great losses, which could be reduced by processing by combined methods (Welti-Chanes et al., 1994).

Food preservation through processing by combined methods is a suitable combination of various hurdles, such as reduction of water activity, lowering $\mathrm{pH}$, simple or combined use of antimicrobial agents and mild thermal treatment, which lead to room temperature stable and also low cost foods (Daza et al., 1997; Welti-Chanes, 1997).

Fruits processed by combined methods can be consumed as if they were fresh or used as components in food formulation such as ice creams, frozen desserts, and yogurts, with an advantage that this type of processing give to fruits a "fresh" and/or "healthy" appearance (Maltini et al., 1993).

One further advantage of processing by combined methods is that original organoleptic characteristics are largerly maintained (Alzamora et al., 1993). This work aimed to evaluate sensory acceptance of fresh and processed melons, mangoes and cashew apples.

\section{MATERIAL AND METHODS}

Cantaloupe melons 'Hi-Mark' (Cucumis melo L. var. cantaloupensis Naud.) and mangoes 'Coite' (Mangifera indica L.) obtained in local market and cashew apples clone CCP 76 (Anacardium occidentale L. var. nanum) from experimental sites of EMBRAPA (Pacajus, CE) were used.

Fruits were received and selected according to their quality attributes, washed in chlorinated water $(50 \mathrm{ppm}$ for 15 $\mathrm{min}$ ), manually peeled and cut in cubes. After blanching at $100^{\circ} \mathrm{C}$ for $2 \mathrm{~min}$, fruits were submitted to osmotic treatment, in sucrose syrup at $25^{\circ}$ Brix for 5 days, at $28-30^{\circ} \mathrm{C}$. A fruit:syrup proportion of 1:2 was used. Syrup was prepared according to Table 1, with different $\mathrm{SO}_{2}$ concentrations. Fruits were packed in high density polyethylene bags at $90^{\circ} \mathrm{C}$ and heat treatment was applied at $100^{\circ} \mathrm{C}$ for one min. After heat treatment, bags were cooled in tap water during 15 minutes until approximately temperature of $28^{\circ} \mathrm{C}$ was reached and samples were taken for sensory analysis.

1 (Trabalho 032/2001). Recebido: 06/02/2001. Aceito para publicação: 04/10/2001.

2 Eng. Alimentos, Dr., pesquisadoras Embrapa Agroindústria Tropical, R. Dra. Sara Mesquita, 2270 - Pici, Fortaleza - CE, CEP 60511-110. Email: renata@cnpat.embrapa.br

3 Eng. Químico, M. Sc. , pesquisador Embrapa Agroindústria Tropical 
Sensory evaluation was conducted with fresh and processed fruits. A nine-point hedonic scale, varying from "dislike extremely" (score 1) to "like extremely" (score 9) was used, according to Stone \& Sidel (1992). Panelists were instructed to determine the acceptance of the single fruit presented. Each panelist evaluated all three fruits, fresh and processed, in randomized order of presentation, in different sessions for each fruit. Private booths and fluorescent lighting were used. Fruits at room temperature were presented to panelists. Thirty untrained panelists evaluated fruits in relation to appearance, aroma, flavor, texture and overall acceptance using the score sheet for acceptance testing presented in Figure 1. Results were analyzed by Analysis of Variance (ANOVA) and mean scores were compared by Tukey's (HSD) test.

\section{RESULTS AND DISCUSSION}

Mean scores obtained for acceptance of fresh and processed melons, mangoes and cashew apples are presented in Tables 2 to 4 .

Sensory acceptance of processed melons treated with $300 \mathrm{ppm}$ of $\mathrm{SO}_{2}$ was equivalent to acceptance to fresh melons, according to Tukey's test $(p<0.05)$ applied for appearance, flavor, texture and overall acceptance (Table 2). Aroma scores of processed melons were lower than those obtained for fresh melons, with scores significantly different $(\mathrm{p}<0.05)$.

Overall acceptance of the fresh and processed fruits was similar. Mean scores observed for overall acceptance of fruits treated with 300 or $900 \mathrm{ppm}$ of $\mathrm{SO}_{2}$ are characteristic of acceptable products. In hedonic scale, this range varies from "like slightly" to "like moderately". Figure 2 presents frequency percentage of hedonic scale scores of overall acceptance, obtained for the fresh and processed fruits. The frequency of responses are more concentrated between scores of 7 and 9 , for fresh and processed fruits, meaning that processed fruit is acceptable as fresh fruit, confirming results of the mean comparison test for overall acceptance.

Fresh mangoes exhibited higher scores for all attributes than processed mangoes, except for flavor. Although significant different scores were observed for fresh and processed mangoes, overall acceptance scores were high for both treatments (Table 3 ). Figure 3 presents the frequency of hedonic scale scores for overall acceptance of fresh and processed mangoes treated with two different levels of $\mathrm{SO}_{2}$. Fresh mangoes received $100 \%$ of responses between 6 and 9 , while processed fruits received 80 and $90 \%$ of their responses between 6 and 9 . This research demonstrated higher acceptance scores for mangoes than those reported by Daza et al. (1997) for processed mangoes, which varied from 4.2 to 7.0 .

Fresh cashew apples exhibited lower scores for flavor, texture and overall acceptance when compared to processed fruits

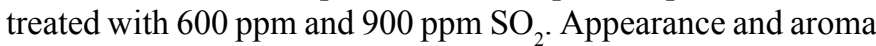
scores were not significantly different between fresh and 900 ppm $\mathrm{SO}_{2}$ treated cashew apples (Table 4). Fresh fruits received $45 \%$ of their scores between 6 ("like slightly") and 9 ("like extremely"), while processed cashew apples received $90 \%$ of their scores between 6 and 9, indicating that processed fruits were better accepted (Figure 4). Differences may be due to a reduction of typical astringency caused by tannins in fresh fruit, when a complex with tannins and added sugar is formed and by

TABLE 1 - Composition of syrups used in osmotic treatment

T R E A T M E N T

\begin{tabular}{|c|c|c|}
\hline Sodium benzoate (ppm) & 1000 & 1000 \\
\hline C itric acid & added up to syrup pH 2.5 & Added up to syrup pH 2.5 \\
\hline A scorbic acid (ppm) & 600 & 600 \\
\hline C alcium chloride (ppm) & 100 & 100 \\
\hline \multicolumn{3}{|l|}{$\mathrm{S}$ ulfur dioxide $-\mathrm{SO}_{2}(\mathrm{ppm})$} \\
\hline melon & 300 & 900 \\
\hline $\mathrm{m}$ a n go & 600 & 900 \\
\hline cashew apple & 600 & 900 \\
\hline
\end{tabular}

TABLE 2 - Mean scores for sensory acceptance for fresh and processed melons

\begin{tabular}{lccc} 
& fresh & $300 \mathrm{ppm} \mathrm{SO}$ & $900 \mathrm{ppm} \mathrm{SO}_{2}$ \\
\hline Appearance & $7.93 \mathrm{a}$ & $7.67 \mathrm{ab}$ & $7.17 \mathrm{~b}$ \\
Aroma & $7.77 \mathrm{a}$ & $6.80 \mathrm{~b}$ & $6.57 \mathrm{~b}$ \\
Flavor & $6.83 \mathrm{a}$ & $6.80 \mathrm{a}$ & $6.90 \mathrm{a}$ \\
Texture & $7.43 \mathrm{a}$ & $7.23 \mathrm{a}$ & $7.03 \mathrm{a}$ \\
Overall acceptance & $7.17 \mathrm{a}$ & $6.93 \mathrm{a}$ & $6.87 \mathrm{a}$ \\
\hline
\end{tabular}

In each row, samples followed by the same letters are not significantly different $(p<0.05)$ 
TABLE 3 - Mean scores for sensory acceptance for fresh and processed mangoes

\begin{tabular}{|c|c|c|c|}
\hline & fresh & $600 \mathrm{ppm} \mathrm{SO}_{2}$ & 900 p p m $\mathrm{SO}_{2}$ \\
\hline Appearance & $7.80 \mathrm{a}$ & $6.73 \mathrm{~b}$ & $6.83 \mathrm{~b}$ \\
\hline A rom a & $7.73 \mathrm{a}$ & $6.80 \mathrm{~b}$ & $7.03 \mathrm{~b}$ \\
\hline F lavor & $7.67 \mathrm{a}$ & $7.10 \mathrm{a}$ & $7.20 \mathrm{a}$ \\
\hline Texture & $7.53 \mathrm{a}$ & $6.27 \mathrm{~b}$ & $6.57 \mathrm{~b}$ \\
\hline Overa 11 acceptance & $7.77 \mathrm{a}$ & $6.97 \mathrm{~b}$ & $6.73 \mathrm{~b}$ \\
\hline
\end{tabular}

In each row, samples followed by the same letters are not significantly different $(\mathrm{p}<0.05)$

TABLE 4. Mean scores for sensory acceptance for fresh and processed cashew apples

\begin{tabular}{lccc} 
& fresh & $600 \mathrm{ppm} \mathrm{SO}_{2}$ & $900 \mathrm{ppm} \mathrm{SO}_{2}$ \\
\hline A ppearance & $6.73 \mathrm{a}$ & $6.20 \mathrm{~b}$ & $6.93 \mathrm{a}$ \\
A roma & $6.77 \mathrm{a}$ & $6.77 \mathrm{a}$ & $7.17 \mathrm{a}$ \\
Flavor & $4.67 \mathrm{~b}$ & $6.87 \mathrm{a}$ & $7.17 \mathrm{a}$ \\
Texture & $6.00 \mathrm{~b}$ & $6.73 \mathrm{a}$ & $6.93 \mathrm{a}$ \\
Overall acceptance & $5.48 \mathrm{~b}$ & $6.73 \mathrm{a}$ & $7.03 \mathrm{a}$ \\
\hline
\end{tabular}

In each row, samples followed by the same letters are not significantly different $(\mathrm{p}<0.05)$

NAME: DATE:

Please, evaluate the fruit sample and indicate how much you like or dislike it for appearance, aroma, taste, texture and overall acceptance.

$$
\text { SAMPLE } \mathrm{N}^{\mathrm{o}} \text { : }
$$

APPEARANCE
( ) like extremely
( ) like very much
( ) like moderately
( ) like slightly
( ) neither like nor dislike
( ) dislike slightly
( ) dislike moderately
( ) dislike very much
( ) dislike extremely

TASTE

( ) like extremely

( ) like very much

( ) like moderately

( ) like slightly

( ) neither like nor dislike

( ) dislike slightly

( ) dislike moderately

( ) dislike very much

( ) dislike extremely

$\begin{array}{ll}\text { TEXTURE } & \text { OVERALL ACCEPTANCE } \\ \text { ( ) like extremely } & \text { ( ) like extremely } \\ \text { ( ) like very much } & \text { ( ) like very much } \\ \text { ( ) like moderately } & \text { ( ) like moderately } \\ \text { ( ) like slightly } & \text { ( ) like slightly } \\ \text { ( ) neither like nor dislike } & \text { ( ) neither like nor dislike } \\ \text { ( ) dislike slightly } & \text { ( ) dislike slightly } \\ \text { ( ) dislike moderately } & \text { ( ) dislike moderately } \\ \text { ( ) dislike very much } & \text { ( ) dislike very much } \\ \text { ( ) dislike extremely } & \text { ( ) dislike extremely }\end{array}$

Comments:

FIGURE 1. Score sheet for acceptance test

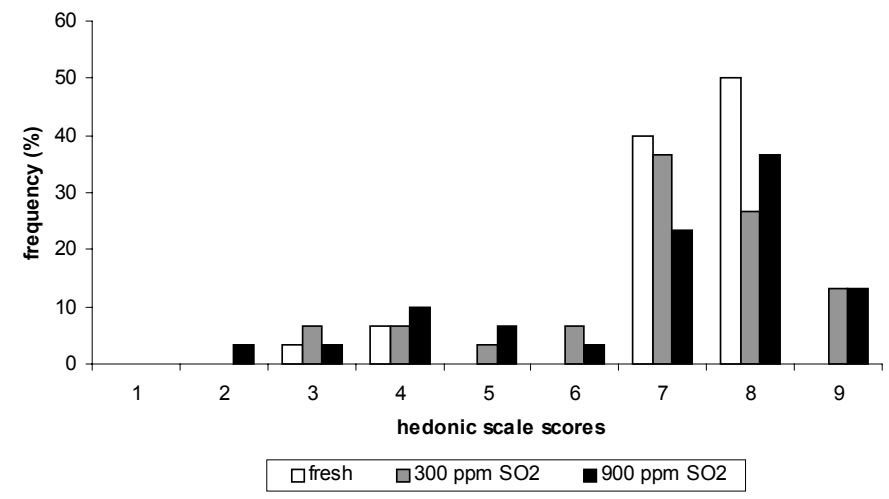

FIGURE 2. Frequency of hedonic scale scores of processed and fresh melons for overall acceptance of products (1=dislike extremely; 9=like extremely)

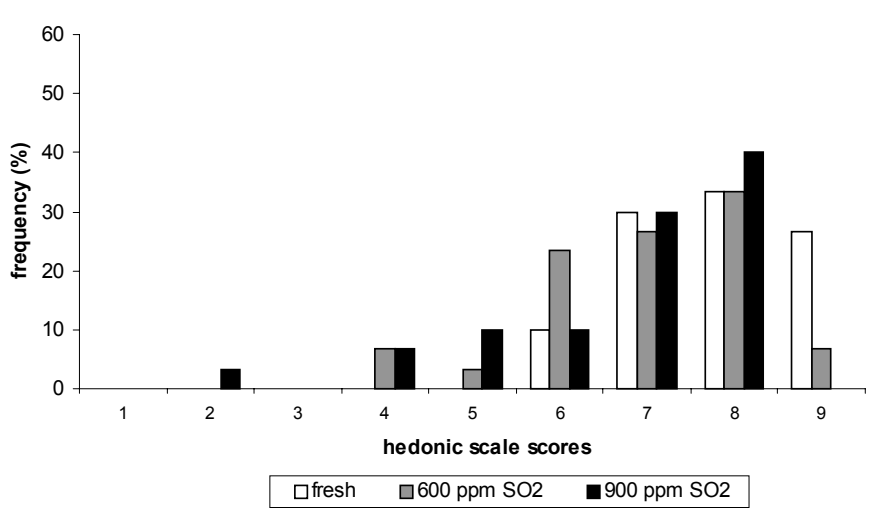

FIGURE 3 - Frequency of hedonic scale scores of processed and fresh mangoes for overall acceptance of products ( $1=$ dislike extremely; $9=$ like extremely) 


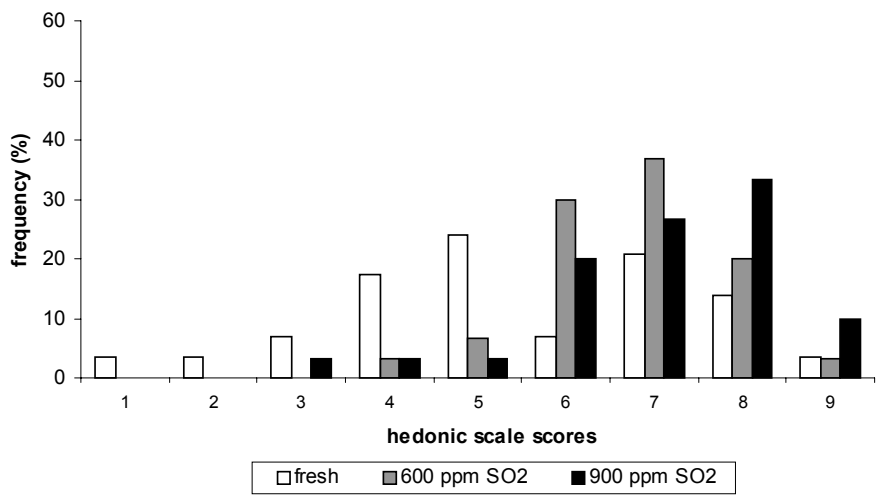

FIGURE 4 - Frequency of hedonic scale scores of processed and fresh cashew apples for overall acceptance of products ( $1=$ dislike extremely; $9=$ like extremely)

degradation of tannins caused during heat treatment.

\section{CONCLUSIONS}

Sensory acceptance results indicated that consumers' acceptance to fresh and processed fruits varied depending on the fruit. While fresh and processed melons received similar acceptance scores, fresh mangoes received higher acceptance scores than processed mangoes and fresh cashew apples received lower acceptance scores than processed cashew apples. Although acceptance scores were different for each processed fruit, combined methods applied resulted in products with good acceptance, which can be used immediately or as ingredient in food formulations.

\section{REFERENCES}

ALZAMORA, S.M.; TAPIA, M.S.; ARGAÍZ, A.; WELTI, J. Application of combined methods technology in minimally processed fruits. Food Research International, Oxford, v.26, n..1, p. 125-130, 1993.

DAZA, M.S.T.; ALZAMORA, S.M.; WELTI-CHANES, J. Minimally processed high-moisture products by combined methods: results of a multinational project. In: FITO, P., ORTEGARODRÍGUEZ, E., BARBOSA-CÁNOVAS, G.V (Ed.) Food engineering 2000. New York: Chapman \& Hall, 1997. p.161-180.

MALTINI,E.; TORREGGIANI, D.; BROVETTO, B.R.; BERTOLO, G. Functional properties of reduced moisture fruits as ingredients in food systems. Food Research International, Oxford, v.26, n.3, p. 413-419, 1993.

STONE, H.; SIDEL, J.L. Sensory evaluation practices. 2. ed. San Diego: Academic Press, 1992.336p.

WELTI-CHANES, J.; ALZAMORA, S.M.; RAPIA, M.S., ARGAÍZ, A. Aplicaciones de los fatores combinados en frutas y hortalizas. In: MAUPOEY, P.F.; GRAU, A.A., BOIX, A.C (Ed.) Aplicación de factores combinados en la conservación de alimentos. New York: Chapman \& Hall, 1994. p. 155-166.

WELTI-CHANES, J.; VERGARA-BALDERAS, F., LOPEZ-MALO, A. Minimally processed foods: state of art and future. In: FITO, P.; ORTEGA-RODRÍGUEZ, E.; BARBOSA-CÁNOVAS, G.V (Ed.) Food engineering 2000. New York: Chapman \& Hall, 1997. p.181212. 